\title{
NEW MARKET SEGMENTATION KNOWLEDGE IN THE FUNGTION OF BIOECONOMY DEVELOPMENT IN SERBIA
}

Nenad Djokic ${ }^{1}$, Aleksandar Grubor ${ }^{2}$, Nikola Milicevic $^{3}$ and Viktorija Petrov ${ }^{4 *}$

1), 2), 3), 4) University of Novi Sad, Faculty of Economics in Subotica, Subotica, Serbia

Please cite this article as:

Djokic, N., Grubor, A., Milicevic, N. and Petrov, V., 2018.

New Market Segmentation Knowledge in the Function of

Bioeconomy Development in Serbia. Amfiteatru

Economic, 20(49), pp. 700-716
Article History

Received: 30 March 2018

Revised: 25 May 2018

Accepted: 28 June 2018

DOI: $10.24818 / \mathrm{EA} / 2018 / 49 / 700$

\begin{abstract}
Sustainability of companies in modern market conditions greately depends on the knowledge. In order to improve their business processes and satisfy the needs of their customers, managers have to rely on new marketing knowledge, especially in new sectors such as bioeconomy. The aim of this paper is to investigate potential added value to Serbian organic food market segmentation researches (belonging to preconditions of further bioeconomy development) when implementing new marketing knowledge - food-related lifestyle market segmentation and scales' testings. The results point out to adventurous consumers as the most important current and future market for organic food. Besides being the most educated (what was already established for consumers accepting organic food well in previous domestic researches), it is the first time that consumers accepting organic food in larger extent are brought in connection to their inclusion of the whole family in the preparation of meals and acceptance of novelties in cooking. It is also the first time to identify that there is a segment in domestic conditions for which price is not the greatest obstacle for increasing organic food consumption. That can be of the great importance for all actors (both national and foreign) operating at domestic food market.
\end{abstract}

Keywords: knowledge marketing, market segmenetation, food-related lifestyle market segmentation, scales' testing, bioeconomy, organic food market, Serbia.

JEL Classification: Q57, D8, M31, Q13

${ }^{*}$ Corresponding author, Viktorija Petrov - viktorija.petrov@ef.uns.ac.rs 


\section{Introduction}

The uncertain and dynamic business environment has determined the knowledge as essential resource for business actors. Capabilities of utilization and generation of knowledge are decisive drivers of firm's performance (Inkinen, 2016, p. 230) that was recognized as phenomenon by pioneering academic discussion that generated knowledge management concept (Davenport and Prusak, 1998; Nonaka and Takeuchi, 1995). Knowledge management is to be considered as an "enabler to the articulation or implementation of strategy" (whose important part is marketing) and is determinant of organizational competitiveness (Dayan, Haisisg and Matos, 2017, p. 313). Four basic processes are regarded as key knowledge management components: creating, storing/retrieving, transferring, and applying knowledge. Knowledge could be acquired as entirely new knowledge, or be created out of existing available knowledge through different ways of collaboration (Kim and Lee, 2010, p. 135).

When it comes to marketing knowledge, there should be a distinction between academic marketing knowledge (MKA) and marketing knowledge used by practitioners (MKP). Differences aside, both have in common the focus on market segmentation. Thus, a motivation for this research is a need to bring closer academic and practical approaches regarding segmentation. A criticism of dominant lifestyle research led to developing new market segmentation concept by Grunert, Brunsø and Bisp (1993) which is called foodrelated lifestyle market segmentation. Although applied in a number of countries, this approach is new to Serbian food market. Furthermore, unlike in some of its previous applications, there is a need to implement new academic marketing knowledge related to appropriate scales' testings.

Previous organic food market segmentation researches in Serbia did not succeed in finding common characteristics of organic food consumers. For the future development of organic food market, it is necessary to know the profile of organic consumer. Furthermore, the role of organic sector in developing sustainable food chain and ensuring global food security is of the greatest importance. Thereby, it can be understood as an achievement of bioeconomy in agricultural sector.

The aim of this paper is to investigate potential added value to Serbian organic food market segmentation researches when implementing new marketing knowledge - food-related lifestyle market segmentation and scales' testings. The paper consists of several parts. At the beginning, sections referring to literature review, explain relationships between different researched topics - bioeconomy and organic food production, as well as knowledge marketing and market segmentation. After that, primary research design and results are presented followed by discussion. By implementing structured personal interviews using the questionnaire and appropriate scales' testings, it was succeeded not only to identify segments similar to those from researches abroad, but also to deeply and innovatively understand organic food acceptance in domestic conditions. Finally, the conclusions are given.

\section{Bioeconomy and organic food production}

The term "bioeconomics" could be traced back to late 1960s when Zeman used it to emphasize the biological bases of almost all economic activities (D'Alisa, Demaria and 
Kallis, 2014, p54). The term used to represent a wide variety of concepts, ranging from "use of biological knowledge for commercial and industrial purposes" to the "concern that unlimited growth would not be compatible with the basic laws of nature" (Lewandowski et al., 2018, p19).

Although the term has been in use for half a century it was not until it occurred in European policy discussions in the middle of the 2000s (McCormick and Kautto, 2013) that it got a deserved wide public attention. The term knowledge-based bioeconomy, has been introduced referring to a production paradigms based on biological processes, the use of natural inputs, minimum energy consumption and the reuse of "waste materials" (European Commission, 2011). Bioeconomy became a flagship project of EU, with the "knowledgebased" prefix keeping it in line with innovation policy highly important for the EU at the time (Birner, 2018).

Comprehension of current bioeconomics agenda and approaches requires understanding of the underlying dynamics that is the Knowledge-Based Bio-Economy (KBBE). New political-economic strategy aims at creating sustainable capital (Clever Consult BVBA, 2010). In this perspective, organic farming is highly knowledge-based, requiring both hightech and indigenous expertise. Organic production is a system of sustainable agriculture based on: the biological balance of the system, rational use of natural resources, use of renewable energy sources, preservation of natural diversity and protection of the environment.

Many achievements of bioeconomy have been identified in agriculture, where terms such as "bio" and "organic" have been successfully established. Hereby, organic food sector has the important role in developing sustainable food chain and ensuring global food security.

Organic production in Serbia is one of the fastest growing sectors with the almost $300 \%$ growth of the area under organic production in the last five years (Chamber of Commerce and Industry of Serbia, 2015), stimulated by the global organic market value exceeding 80 billion USD (Simic, 2017). The supply of organic products on the local market, from both domestic production and imports, has been expanding in previous years. However, it is still limited in terms of the range and quantities of products available. Moreover, the expansion of the domestic market is hindered by the insufficient purchasing power of consumers. Although the disposable income of the typical Serbian consumer increased over the past ten years, that was overcompensated by an even stronger rise in food prices, limiting the growth of consumption of organic produce. The retail sector for organic food in Serbia is still underdeveloped. Specialized retail outlets offering exclusively organic products are very few, and so fresh and processed organic products mostly make up part of the general offer. Although organic products have found their way to supermarket chains, not much has been done to promote them and improve their availability, leaving consumers to discover organic products on their own, and to recognize their advantages over the conventional ones.

There are different views regarding future development of organic agriculture. In that sense, some authors predominantly support promoting export of domestic organic food (Maslac, 2009; März et al., 2012), while others dominantly support further development of domestic organic food market (Sudarević, Salai and Pupovac, 2011; Renko et al., 2011). Although different regarding views of desirable dominant direction of domestic organic agriculture future development, all the authors support the research of domestic consumers. 
The main contribution of the paper is providing more profound insight into organic food market segmentation in Serbia based on sound methodological bases.

\section{Knowledge marketing and market segmentation}

Employing all available resources as efficiently as possible is the imperative of business actors in the fierce competitive market conditions, as an essential resource is knowledge. According to Roth at al. (2009) knowledge represents strategically important source of competitive advantage, and its effective use cannot be considered a trivial issue.

Effective application of knowledge is becoming the core competitive differentiator (Bahrami and Evans, 2005, p. 1) and special attention in research has been drawn to its: generation, application and sharing in the entire business process. Knowledge, as a strategic resource, commands management in order for competitive advantage to be achieved (Newell et al., 2002). In other words: knowledge leads strategy, and strategy leads knowledge management (Snyman and Kruger, 2004). Stepping up the pace of change requires the use of advanced knowledge-intensive services and cooperation with change management professionals (Cătoiu, Tudor and Bisa, 2016).

For Cader (2007, p. 47), the overall goal of knowledge management "is to build an organization that can "see" the customer (customer-focused), for it is the customer that drives any business". Nowadays, in most markets, customers' demands and whishes are the starting point for almost all activities. If they are not fulfilled in an adequate way, the organizations are not only going to endanger their current revenue, but they can jeopardize their future sustainability as well. There are many competitors who are waiting for others' mistakes, combating for each customer. Thus, in order to satisfy customers' expectations and prevent them to leave to a competitor, significant attention must be paid to marketing knowledge.

Bearing in mind that marketing has been recognized as a separate research field almost 100 years ago, it has generated a large body of knowledge, including many models, concepts, theories and empirical studies (Eisend, 2015). A representation of innovative development of marketing knowledge can be observed in the case of emotional marketing. Rytel (2010, p. 31-32) considers emotional marketing as a concept and defines it as: "a new paradigmatic approach or a new marketing shift, where management (creation, support, evaluation) of emotional link between the company and the consumer (or other market players) becomes the key exchange-stimulating feature." Hill (2003) points out to neurological discoveries according to which there is a domination of subconscious, people feel before they think (the model of decision making is in accordance to following path: sense-feel-(think)-do), and they think in images. Based on development of brain science and with understanding that consumers decisions are under the influence of their emotions to a large extent, the same author (2007) suggests necessary changes in marketing research i.e. the need for it to become more holistic and include not only respondents thoughts but their feelings as well. The same author (2017) points out to difference between emotions (which occur subconsciously and spontaneously) and feelings (that are cognitively filtered instances of self-reporting). Hereby, he stresses facial coding as a tool for deeper understanding of customers. The implications of having knowledge on consumers' emotions are important. Magids, Zorfas and Leemon (2015) point out that "emotional motivators" (the feelings that determine behavior of consumers) can be measured and 
targeted and can be understood as a source of growth and profitability of companies since it measures companies' values from consumer perspective more accurately even than brand awareness and customer satisfaction. Hill (2008) also stresses that success in managing consumers' emotions determines company's sale and productivity.

Following Rossiter (2001, p. 9), marketing knowledge is "what marketing academics and consultants teach and marketing managers draw upon in formulating marketing plans". The same author (2001) differentiates this term from marketing skills. Strong relations aside, marketing knowledge must be independent from practitioners' ability to perform it, so that it can be documented and articulated to others. Rossiter (2001) proposed four main hierarchical forms of marketing knowledge, which later he revised into five (Rossiter, 2002): marketing concepts (marketing terms, described and defined by main attributes), structural frameworks (descriptive lists of concepts), empirical generalizations ("if, then" relations between concepts), strategic principles ("if, do" relations between concepts) and research principles ("if, use" statements of the appropriate research technique).

On the other hand, Wierenga (2002) distinguishes academic marketing knowledge (MKA) and marketing knowledge used by practitioners (MKP). Academic marketing knowledge, characterized by terms such as marketing principles, marketing laws, marketing science etc, is related to analytical, systematic and empirical research of marketing phenomena. Despite its significant growth, the MKA is not enough for decision making process. In addition to formal marketing education, marketing practitioners rely on their experience, which results in a mental model used for diagnosing and solving problems. Marketing knowledge used by practitioners also refers to analogies, intuition and creativity of decision makers (Wierenga, 2002).

The relation between MKA and MKP opens the question of the knowledge exchange between marketing academics and practitioners. Indirect way of knowledge dissemination and long time for its implementation can also cause the knowledge gap between two groups of market knowledge creators and users. Thus, to fill the gap, academics should get close to reality in their research and establish the link with practice. According to Hughes, Tapp and Hughes (2008) academic marketing research and teaching have been exposed to criticism due to its distinction from practice. Their research has shown that academics perceived the main problem as inappropriate use of theory by practitioners, while practitioners stated that they pay attention to the theory, as long as it contributes to their business context. A topic that draws attention of both groups is the topic of market segmentation (Wedel and Kamakura, 2002).

A lively debate among theoreticians and practitioners focusing on the need to bring academic and practical approaches to market segmentation closer could be identified. In that context, Grunert, Bruns $\varnothing$ and Bisp (1993) pointed out to criticism of prevailing lifestyle research. The authors developed market segmentation concept and its instrument, which sustained and extended previous work, integrating cognitive approaches to analysing consumer behaviour like: means-end chains and cognitive structure research. New cognitive, deductive approach to lifestyle research was proposed. The questionnaire is kept as the basic form of operationalization, while dimensions to be measured are formulated in advance, based on theory. The authors proposed a definition of a consumption-related lifestyle by which it is the system of cognitive categories, scripts, and their associations, which relate a set of products to a set of values. 
According to described approach, lifestyle transcends individual brands or products. The lifestyle could be specific to a product class, and thus a food-related lifestyle could be examined.

Food-related lifestyle is the general pattern of how consumers use food to fulfil basic motives or attain life values. The food-related lifestyle instrument (Bruns $\varnothing$, Grunert and Bredahl, 1996) consists of 69 questions in regard to 5 domains (ways of shopping, quality aspects, cooking methods, consumption situations, purchasing motives) consisting of the total of 23 lifestyle dimensions (see figure no. 1) - whereas 6, 6, 6, 2 and 3 dimensions belong to appropriate domains, respectively. It has been implemented in lifestyle research and for a product specific group lifestyle in a number of countries and several studies supported cross-cultural and/or cross-temporal validity of the instrument used for performing this segmentation (table no. 1). Although additional market segments have been discovered in some of the researches, Brunsø, Fjord and Grunert (2002) found common market segments in most of them: the uninvolved food consumers, the careless food consumers, the conservative food consumers, the rational food consumers and the adventurous food consumers.

While the practical application of the segmentation approach in focus is important and beneficial, there is a need to implement academic marketing knowledge related to appropriate scales' testing (Churchill, 1979; Anderson and Gerbing, 1982; Danes and Mann, 1984; Steenkamp and van Trijp, 1991). The potential adequate procedure could be implemented in two phases. In the first application, for testing the reliability, Cronbach's alpha, Cronbach's alpha if item deleted, and Corrected item-total correlation should be calculated separately for each of 23 lifestyle dimensions. Besides, exploratory factor analysis by (for example, maximum likelihood factor analysis method and Varimax rotation method) can be implemented for testing validity within each of five life domains. Prior to Exploratory factor analysis, adequacy of conducting it should be tested by Kaiser-Meyer-Olkin (KMO) test and Bartlett's Test of Sphericity. In the second research stage, for new testing of the reliability, Cronbach's alpha, Cronbach's alpha if item deleted, and Corrected item-total correlation should calculated for each of 23 lifestyle dimensions. Confirmatory factor analysis (with maximum likelihood method) can be used within each of the life domains.

Only after all necessary testing procedures have been conducted, and omissions of items in accordance to previous tests' results made, cluster analysis can be performed. Clustering based on means of each lifestyle dimensions, using Squared Euclidean Distance for example, used as the distance measures, and Ward's method for grouping respondents into clusters).

The level of the implementation of previously described procedures in some of earlier studies can be seen in the column scales' testing in table no. 1 .

Table no. 1: Overview of Food-related lifestyle market segmentation (FRLS) research

\begin{tabular}{|l|l|l|l|}
\hline Source & Topic & Scales' testing & Main findings \\
\hline $\begin{array}{l}\text { Bruns } \emptyset, \\
\text { Grunert and } \\
\text { Bredahl } \\
(1996)\end{array}$ & $\begin{array}{l}\text { existence of cross- } \\
\text { national food } \\
\text { consumer segments }\end{array}$ & $\begin{array}{l}\text { exploratory factor } \\
\text { analysis, confirmatory } \\
\text { factor analysis }\end{array}$ & $\begin{array}{l}\text { strong tendency towards cross- } \\
\text { national segments }\end{array}$ \\
\hline $\begin{array}{l}\text { Bredahl and } \\
\text { Grunert } \\
(1997)\end{array}$ & $\begin{array}{l}\text { cross-temporal } \\
\text { validity of the data }\end{array}$ & $\begin{array}{l}\text { exploratory factor } \\
\text { analysis, discriminant } \\
\text { analysis }\end{array}$ & $\begin{array}{l}\text { - cross-temporal validity support } \\
\text { - consumers more convenience- } \\
\text { oriented, security as important } \\
\text { purchasing motive }\end{array}$ \\
\hline
\end{tabular}




\begin{tabular}{|c|c|c|c|}
\hline Source & Topic & Scales' testing & Main findings \\
\hline $\begin{array}{l}\text { Reid, Bruwer } \\
\text { and Grunert } \\
(2001)\end{array}$ & $\begin{array}{l}\text { lifestyles in } \\
\text { Australia and four } \\
\text { other countries } \\
\text { comparison }\end{array}$ & Cronbach's alpha & $\begin{array}{l}\text { some of important differences } \\
\text { between Australia and Singapore, } \\
\text { United Kingdom, France, and } \\
\text { Denmark persist }\end{array}$ \\
\hline $\begin{array}{l}\text { Bruwer, Li } \\
\text { and Reid } \\
\text { (2002) }\end{array}$ & $\begin{array}{l}\text { wine-related } \\
\text { lifestyle instrument } \\
\text { development }\end{array}$ & $\begin{array}{l}\text { Cronbach's alpha, } \\
\text { exploratory factor } \\
\text { analysis }\end{array}$ & $\begin{array}{l}\text { instrument developed (in } \\
\text { accordance to FRLS), segments } \\
\text { identified }\end{array}$ \\
\hline $\begin{array}{l}\text { Kesić and Piri } \\
\text { Rajh (2003) } \\
\end{array}$ & $\begin{array}{l}\text { FRLS segmentation } \\
\text { in Croatia } \\
\end{array}$ & - & segments identified \\
\hline $\begin{array}{l}\text { Ryan et al. } \\
(2004)\end{array}$ & $\begin{array}{l}\text { FRLS segmentation } \\
\text { in Ireland }\end{array}$ & $\begin{array}{l}\text { Cronbach's alpha, } \\
\text { exploratory factor } \\
\text { analysis }\end{array}$ & segments identified \\
\hline $\begin{array}{l}\text { Scholderer et } \\
\text { al. (2004) }\end{array}$ & $\begin{array}{l}\text { cross-cultural and } \\
\text { cross-temporal } \\
\text { validity }\end{array}$ & $\begin{array}{l}\text { multi-sample } \\
\text { confirmatory factor } \\
\text { analysis with structured } \\
\text { means }\end{array}$ & instrument's validity support \\
\hline $\begin{array}{l}\text { O'Sullivan, } \\
\text { Scholderer } \\
\text { and Cowan } \\
(2005)\end{array}$ & $\begin{array}{l}\text { cross-cultural } \\
\text { validity of the } \\
\text { instrument }\end{array}$ & $\begin{array}{l}\text { confirmatory factor } \\
\text { analysis }\end{array}$ & $\begin{array}{l}\text { instrument completely } \\
\text { invariant across the two cultures }\end{array}$ \\
\hline $\begin{array}{l}\text { Fang and Lee } \\
(2009)\end{array}$ & $\begin{array}{l}\text { FRLS segmentation } \\
\text { in Taiwan }\end{array}$ & $\begin{array}{l}\text { Cronbach's alpha, } \\
\text { exploratory factor } \\
\text { analysis }\end{array}$ & segments identified \\
\hline $\begin{array}{l}\text { Nie and } \\
\text { Zepeda (2011) }\end{array}$ & $\begin{array}{l}\text { FRLS segments; } \\
\text { organic and local } \\
\text { food consumption }\end{array}$ & - & $\begin{array}{l}\text { segments (identified based on } \\
\text { adapted instrument) significantly } \\
\text { differed in organic and local food } \\
\text { consumption }\end{array}$ \\
\hline $\begin{array}{l}\text { Szakály et al. } \\
\text { (2012) }\end{array}$ & $\begin{array}{l}\text { FRLS segments and } \\
\text { functional food } \\
\text { preferences }\end{array}$ & $\begin{array}{l}\text { exploratory factor } \\
\text { analysis }\end{array}$ & $\begin{array}{l}\text { significant relationship } \\
\text { between lifestyle, health behavior, } \\
\text { and the preference for functional } \\
\text { food }\end{array}$ \\
\hline
\end{tabular}

Previous organic food market segmentation researches in Serbia did not succeed in finding common characteristics of organic food consumers. Đokić et al. (2014) based on a convenience sample of 300 respondents, aged 20 to 65 defined the organic food consumers as: people consuming organic food at least once a week and identified them as being mostly higher income female, highly educated, married with children and having larger households. Kalentic et al. (2014) claimed that the typical organic food customer in Serbia was woman aged from 25 to 40, educated and aware of the impact of unsafe food on health. Grubor and Djokic (2016) identified, based on preference-based market segmentation conducted by using conjoint and cluster analysis, a segment which preferred organic food (in concrete case yoghurt) the most.

Although authors described the profile of the "preferring organic yoghurt" segment, the socio-demographic features were similar to consumers named "appearance-conscious innovators" and there were no socio-demographic characteristics significantly different from consumers in other identified segments. What is proven is that actual and potential consumers of organic food could be related only to higher incomes and especially higher levels of education (Djokic and Milicevic, 2016). 
Previously mentioned domestic research is heterogeneous in some extent in their settings, implementation and processing. Consequently the findings are diverse, even regarding variables that are used in all of them, like gender and age.

\section{Primary research design}

The questionnaire consisted of three parts. The first part was FRLS questionnaire. All items were rated on a seven-point Likert scale ranging from "strongly disagree" to "strongly agree". The second part of the questionnaire referred to potential descriptors of the segments. It related to respondents' socio-demographic characteristics. The third part of the questionnaire consisted of questions regarding respondents' self-reported frequency of actual and preferred consumption of organic food. Self-reported frequency of consumption was assessed at a seven-point Likert scale with following levels: level 1 - never, level 2 once in several months, level 3 - once in several weeks, level 4 - once a week, level 5 several times a week, level 6 - every day, level 7 - several times a day. The respondents whose preferred organic food consumption was higher than the actual consumption were asked whether the main obstacle to transforming preferences into actual consumption was price, availability or lack of trust that products marketed as organic were actually organic.

Structured interviews were employed in personal communication with the respondents within the research method. Convenience sampling method was used. In an attempt to reach the average Serbian consumer, the respondents (from the population of 18 to 65 years of age) were approached near green markets, large shopping centres and university centres, simultaneously in several larger Serbian towns, as well as in the city of Belgrade. It was decided that the person to be interviewed should be the one responsible for cooking or buying food in the household.

After elimination of questionnaires with incomplete answers and the respondents who scored low or high on all dimensions, 420 questionnaires were included in the final analysis ("average consumer" in table no. 2). The size of a sample in this research is somewhat greater than in other listed domestic researches (ranging from 300 to 400 respondents). To test reliability and validity of the FRLS questionnaire, 350 answers were taken into account. Data collection was carried out from October 2015 to November 2015.

Scales' testing was performed in accordance to procedure described previously in the paper. Furthermore, when identifying differences between clusters in relation to the selected numeric segmentation variables, one-way ANOVA with Tukey post-hoc test was used. Ordinary variables required employment of Kruskal-Wallis test, where the differences between each two clusters were established by means of Man-Whitney tests. When the differences between clusters were established by variables that are nominal, Chi-Square test was used. Data was processed in the SPSS and AMOS statistical packages, as well as the Microsoft Office Excel.

\section{Results and discussion}

Taking into account the results of previous FRLS applications, the interpretability of the results and observation of the dendrograms, three clusters i.e. consumer segments were identified. The distribution of respondents by clusters in terms of their relative size, were as 
follows: the first cluster included 256 respondents $(61 \%)$, the second $93(22.1 \%)$ and the third $71(16.9 \%)$.

Socio-demographic characteristics of an average consumer and consumers from different segments, as well as existence of statistically significant differences between segments in regard to these characteristics, are presented in table no. 2 .

Table no. 2: Food-related lifestyle market segments' general characteristics

\begin{tabular}{|c|c|c|c|c|c|c|c|c|c|}
\hline \multirow[b]{2}{*}{ Characteristics } & \multirow[b]{2}{*}{ 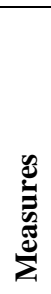 } & \multicolumn{4}{|c|}{ Data for } & \multicolumn{4}{|c|}{ Significant differences } \\
\hline & & 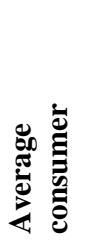 & 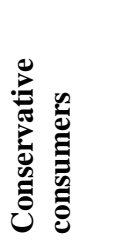 & 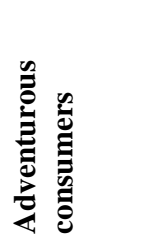 & 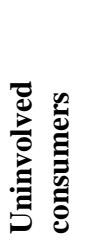 & 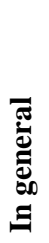 & 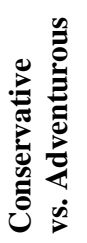 & 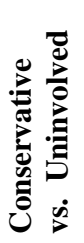 & 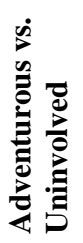 \\
\hline Male & \multirow{14}{*}{ ع } & 36.7 & 32.4 & 25.8 & 66.2 & \multirow[b]{2}{*}{ s. } & \multirow[b]{2}{*}{ n.s. } & \multirow[b]{2}{*}{ s. } & \multirow[b]{2}{*}{ s. } \\
\hline Female & & 63.3 & 67.6 & 74.2 & 33.8 & & & & \\
\hline Married & & 61.2 & 73.4 & 67.7 & 8.5 & \multirow{2}{*}{ s. } & \multirow[b]{2}{*}{ n.s. } & \multirow{2}{*}{ s. } & \multirow{2}{*}{ s. } \\
\hline Single & & 38.8 & 26.6 & 32.3 & 91.5 & & & & \\
\hline No children & & 48.6 & 39.5 & 50.5 & 78.9 & \multirow{2}{*}{ s. } & \multirow{2}{*}{ n.s. } & \multirow{2}{*}{ s. } & \multirow{2}{*}{ s. } \\
\hline With children & & 51.4 & 60.5 & 49.5 & 21.1 & & & & \\
\hline Secondary school & & 40.7 & 58.2 & 5.4 & 23.9 & \multirow{3}{*}{ s. } & \multirow{3}{*}{ s. } & \multirow{3}{*}{ s. } & \multirow{3}{*}{ s. } \\
\hline Student & & 13.8 & 14.8 & 5.4 & 21.1 & & & & \\
\hline College or faculty & & 45.5 & 27.0 & 89.2 & 54.9 & & & & \\
\hline Unemployed & & 20.5 & 25.0 & 11.8 & 15.5 & \multirow{3}{*}{ s. } & \multirow{3}{*}{ s. } & \multirow{3}{*}{ n.s. } & \multirow{3}{*}{ n.s. } \\
\hline State-employed & & 28.1 & 25.0 & 39.8 & 23.9 & & & & \\
\hline Private sector & & 51.4 & 50.0 & 48.4 & 60.6 & & & & \\
\hline From urban place & & 59.5 & 54.7 & 58.1 & 78.9 & \multirow[b]{2}{*}{ s. } & \multirow[b]{2}{*}{ n.s. } & \multirow[b]{2}{*}{ s. } & \multirow[b]{2}{*}{ s. } \\
\hline From rural place & & 40.5 & 45.3 & 41.9 & 21.1 & & & & \\
\hline Age & \multirow{3}{*}{$\frac{\widehat{\hat{\theta}}}{2}$} & $\begin{array}{l}37.20 \\
(13.2)\end{array}$ & $\begin{array}{l}39.22 \\
(13.3) \\
\end{array}$ & $\begin{array}{c}33.96 \\
(10.6) \\
\end{array}$ & $\begin{array}{l}34.13 \\
(14.5) \\
\end{array}$ & s. & s. & s. & s. \\
\hline Household size & & $\begin{array}{l}2.82 \\
(1.3) \\
\end{array}$ & $\begin{array}{l}3.33 \\
(1.1) \\
\end{array}$ & $2.73(1.1)$ & $\begin{array}{l}1.13 \\
(0.6)\end{array}$ & s. & s. & s. & n.s. \\
\hline $\begin{array}{l}\text { Self-assessed } \\
\text { household income } \\
\text { (from } 1 \text { to } 5 \text { ) }\end{array}$ & & $\begin{array}{l}2.94 \\
(0.8)\end{array}$ & $\begin{array}{l}2.63 \\
(0.6)\end{array}$ & $3.20(0.8)$ & $\begin{array}{l}3.73 \\
(0.8)\end{array}$ & s. & s. & s. & s. \\
\hline
\end{tabular}

Notes: M-mean. SD-standard deviation, s.-significant at $p<0.05$, n.s.-not significant

Valuation of different food related lifestyle dimensions by the average consumer, as well as by consumers belonging to different market segments are shown in figure no. 1 .

In general, it can be seen that, when it comes to food related lifestyle dimensions' valuation, the average consumer is rather traditional. Taste is considered the most important dimension, followed by freshness, health and price / quality relation. On the other hand, eating out was not widely recognized as social event just as preparing food was not understood as a task for the whole family. The most important dimensions are consistent with previous research conducted in domestic conditions (Grubor et al. 2015). 
Focusing differences in valuation of food-related lifestyle dimensions between the first segment and the average consumer, it can be concluded that the results are considerably similar. However, respondents in the first segment pay greater attention to shopping lists, consider cooking a woman's task and find price and security important, while they are less open to unfamiliar recipes. In terms of socio-demographic characteristics, these consumers are similar to the average consumer from the sample - most of them are married women with children. These respondents are older than the respondents from the other two segments. Their households are the largest but household income is the lowest. These consumers can be identified as the conservative food consumers.

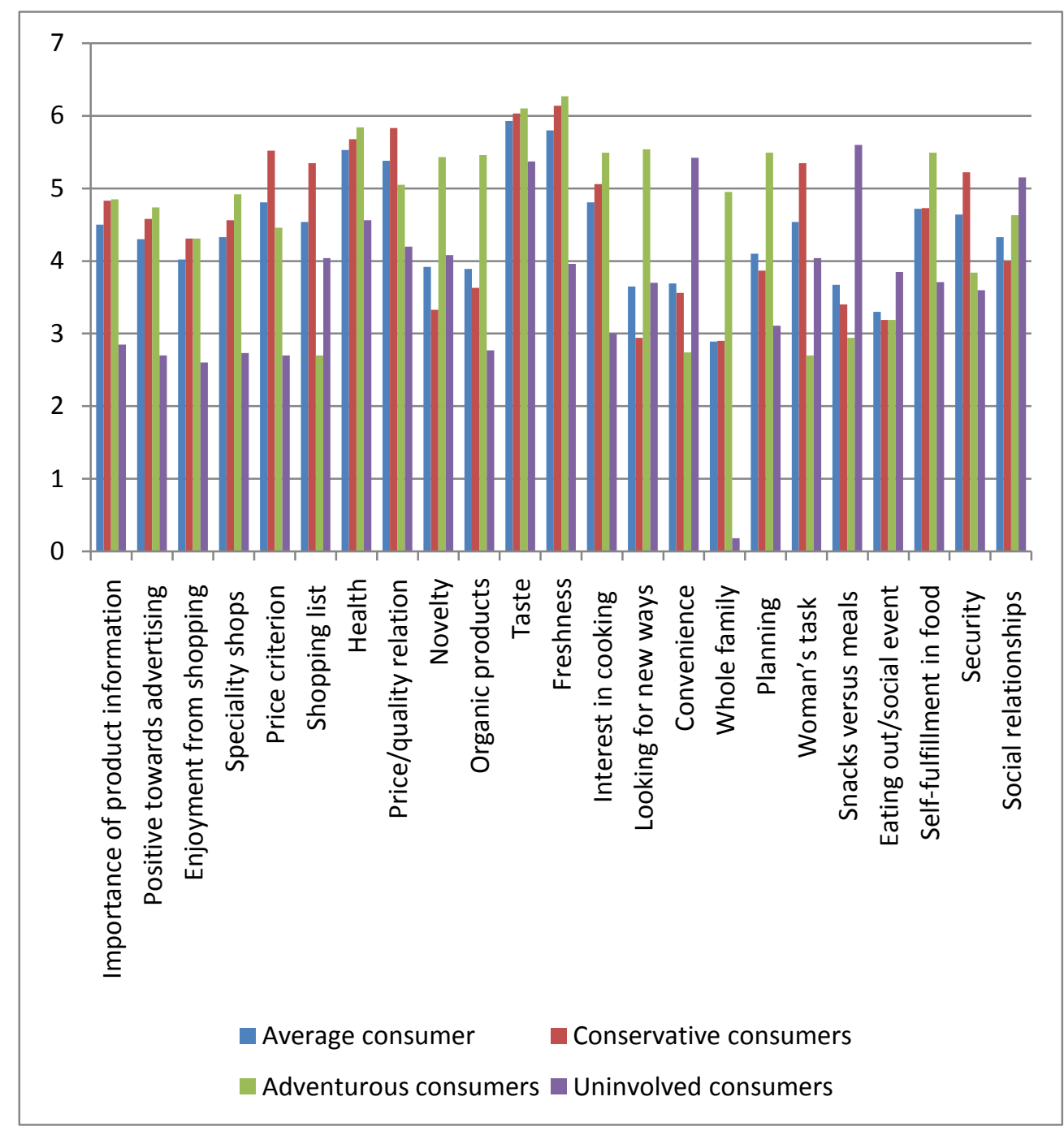

Figure no. 1: Market segments and lifestyle dimensions

Consumers in the second segment differ from the average consumer in the sense that the whole family is included in the cooking process, they strongly reject the idea that it is a 
woman's task, and they accept novelties, organic products and speciality shops. Although they plan in advance what to eat, they do not tend to make shopping lists when purchasing. They are interested in cooking and motivated by self-fulfilment in food. Convenience in cooking and security as purchasing motives are not very important to them. They also reject snacks instead of regular meals. Most of these consumers are also married women with children. They are the most educated and although most of them are employed in the private sector, when compared to the other two segments, there are more of them who are employed by the state. These consumers can be called the adventurous food consumers.

Respondents in the third segment differ from the average consumer considerably in the sense that they are open to snacks and pay great attention to convenience. They also consider eating out a social event and are open to developing social relationships during meals. However, they strongly oppose the idea of finding out information about food and are not even too interested in price. These consumers are not interested in getting engaged in food preparation and do not consider security an important purchasing motive. They are also not eager to accept organic food. These consumers, who can be treated as uninvolved food consumers, are single urban men, with no children and with highest household income.

The description of segments largely resembles profiles of segments found in research in other countries (Brunsø, Fjord and Grunert, 2002).

Differences between segments in relation to organic food consumption and preference are given in table no. 3 .

Table no. 3: Food-related lifestyle market segments and organic food consumption

\begin{tabular}{|c|c|c|c|c|c|c|c|c|c|}
\hline \multirow{3}{*}{$\begin{array}{l}\text { Frequency } \\
\text { of consumption } \\
\text { of organic food }\end{array}$} & \multirow[b]{3}{*}{ 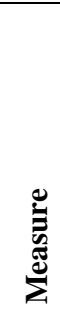 } & \multicolumn{8}{|c|}{ Data for } \\
\hline & & \multicolumn{2}{|c|}{$\begin{array}{l}\text { Average } \\
\text { consumer }\end{array}$} & \multicolumn{2}{|c|}{$\begin{array}{c}\text { Conservative } \\
\text { consumers }\end{array}$} & \multicolumn{2}{|c|}{$\begin{array}{l}\text { Adventurous } \\
\text { consumers }\end{array}$} & \multicolumn{2}{|c|}{$\begin{array}{l}\text { Uninvolved } \\
\text { consumers }\end{array}$} \\
\hline & & 胥 & 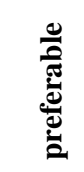 & 胥 & 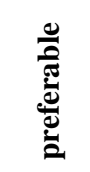 & 胥 & 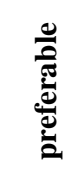 & 预 & 营 \\
\hline never & \multirow{7}{*}{ 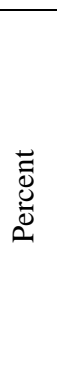 } & 46.7 & 44.8 & 54.7 & 54.3 & 5.4 & 0.0 & 71.8 & 69.0 \\
\hline $\begin{array}{l}\text { once in several } \\
\text { months }\end{array}$ & & 15.5 & 12.4 & 18.4 & 14.8 & 3.2 & 3.2 & 21.1 & 15.5 \\
\hline $\begin{array}{l}\text { once in several } \\
\text { weeks }\end{array}$ & & 21.4 & 8.8 & 20.3 & 9.8 & 36.6 & 5.4 & 5.6 & 9.9 \\
\hline once a week & & 14.3 & 17.4 & 5.5 & 16.0 & 48.4 & 31.2 & 1.4 & 4.2 \\
\hline $\begin{array}{l}\text { several times a } \\
\text { week }\end{array}$ & & 1.9 & 9.5 & 0.8 & 2.3 & 5.5 & 35.5 & 0.0 & 1.4 \\
\hline every day & & 0.2 & 6.2 & 0.4 & 0.0 & 0.0 & 22.6 & 0.0 & 0.0 \\
\hline several times a day & & 0.0 & 1.0 & 0.0 & 0.0 & 0.0 & 2.2 & 0.0 & 0.0 \\
\hline
\end{tabular}

Results indicate that the conservative food consumers are rather similar to the average consumer in the sense that almost $50 \%$ of them do not consume organic food and do not even show preference for consumption of this kind, the adventurous food consumers do consume organic food and show preference for considerably higher consumption than the actual one, while uninvolved food consumers are much less interested in organic food. 
Results of statistical tests show that there are statistically significant differences between segments when it comes to organic food consumption: $c^{2}(2, n=420)=152.696$; $\mathrm{p}=0.000<0.05$, as well as organic food preference $\mathrm{c}^{2}(2, \mathrm{n}=420)=181.317 ; \mathrm{p}=0.000<0.05$. Further testing shows that in both cases there are statistically significant differences between all three segments.

Although both, conservative and adventurous food consumers rank health among their priorities, this does not necessarily translate into consumption or preference to organic food, which is often associated with health (Hughner et al. 2007). As for the conservative food consumers this partly resembles to the results of previous research whereby consumers in Serbia predominantly manifested their general interest in health by consuming functional food, while frequency of consumption of organic food is correlated only with their interest in natural products (Grubor et al. 2015).

The most educated are adventurous food consumers which is in line with the related findings from other countries (Brunsø, Fjord and Grunert, 2002), as well as previous research studies in Serbia that pointed to positive correlation between consumers' interest in organic food and high levels of education (Đokić et al., 2014; Kalentic et al., 2014; Djokic and Milicevic, 2016). However, by applying food-related lifestyle market segmentation, much broader description of the segment favouring organic food is obtained.

Obstacles of organic food consumption are presented in figure no. 2.

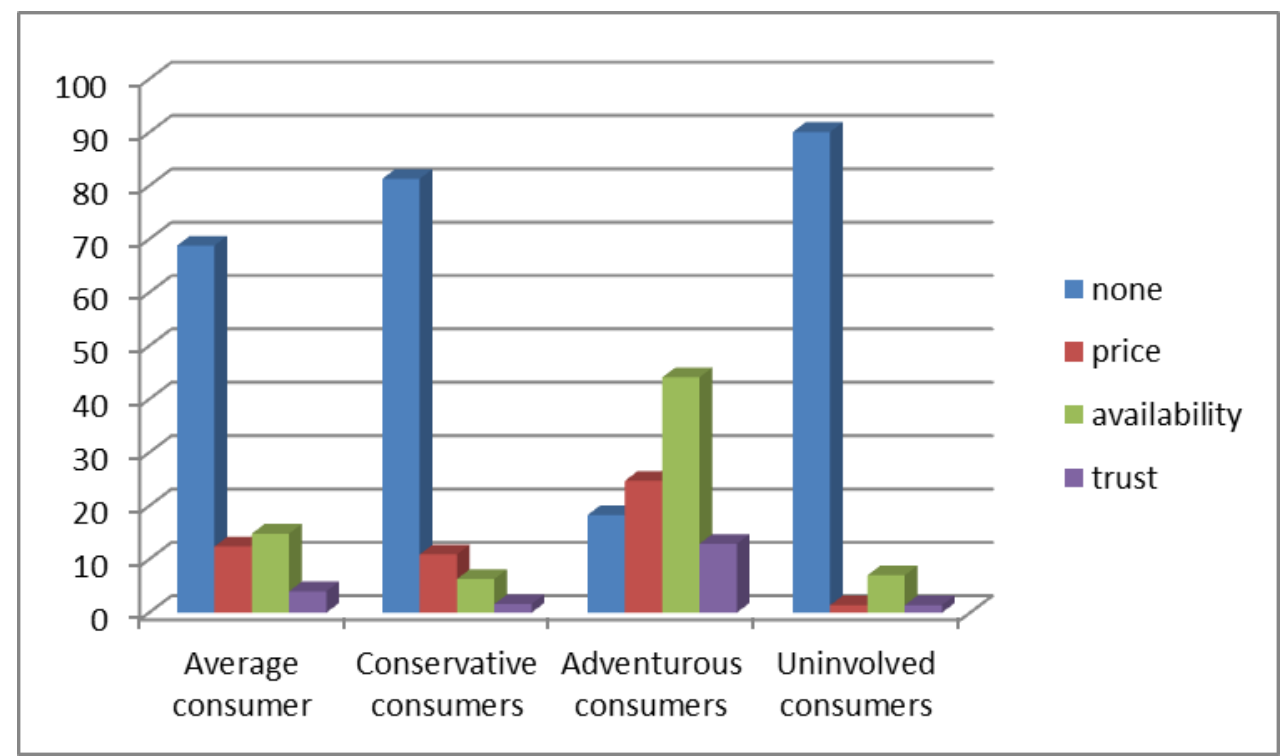

Figure no. 2: Market segments and obstacles of transforming preferences into purchases of organic food

When it comes to obstacles to transforming preferences for organic food into consumption of this type of food (figure no. 2), an important result to be stressed is that within the segment of adventurous food consumers, the actual consumption of organic food is the highest while at the same time the majority of the adventurous consumers showed preference for further increase in consumption. The greatest obstacle for them is 
availability, while price is the second most important. The most important obstacle for buying organic food by adventurous consumers is not the same as identified by previous domestic research (Djokic and Milicevic 2016). When it comes to availability, suppliers can try to reach this segment in a more efficient way when familiar with its profile. Besides, confidence that the product is actually organic (especially in the light of the fact that there are a number of products on the domestic market claimed to be organic without proper certification) is also an important element and suggests need for certification.

\section{Conclusions}

Increasing consumption of organic products has enabled high turnovers in the organic industry sector in Serbia. Proved as lucrative business, offering organic products is highly dependent on knowing the customer. This research has provided academic knowledge valuable for practitioners, thus bridging the gap of the two groups. Based on a 420 respondents' attitudes meticulously analysed by a complete set of scales' tests and adequate analysis followed by testing differences, results could be regarded as a new marketing knowledge in national context.

Some contributions of the paper are: 1) the first application of food-related market segmentation in Serbia; 2) appropriate scales' testing and 3) new information about domestic consumer accepting organic food well.

When considering the first two listed contributions it can be concluded from theoretical/methodological aspect: Only the use of the questionnaire designed in accordance to marketing knowledge and its appropriate implementation can lead to potential discovery of relevant and new information about the topic of interest. In the concrete case, adequate application of FRLS in Serbia, belonging to academic marketing knowledge, lead to acquisition of marketing knowledge usable for practitioners.

The most important segment, i.e. market for organic food, is presented in the analysis and named adventurous consumers. One of the dominant characteristics is the highest education, which was expected as was already established in previous national research. However, the originality is that consumers accepting organic food are brought in connection to their inclusion of the whole family in the preparation of meals and acceptance of novelties in cooking. It is also the first time to identify that there is a segment in national market conditions for which price is not the greatest obstacle for increasing organic food consumption.

The results can have important implications how to create, deliver and communicate the value to the customer and integrate organic food with all these elements. Representatives from supply side of organic food market should choose concentrated marketing strategy and target adventurous consumers. This is due to possibility and preference to increase organic food consumption in this segment. In positioning, they do not need to use primarily characteristic appeals to naturalness, health or tradition, but should focus on organic food as part of lifestyle of modern families - that are interested in novelties in cooking and include the whole family in that process. Innovative recipes can be shown to this segment and they need to include organic food. The visual appearance of the brands should be modern. Organic food suppliers could consider possibilities of online ordering of organic food since low availability is the greatest obstacle for its consumption. Digital marketing tools can be 
used in order to target this segment more precisely. Hereby, the knowledge from emotional marketing should be taken into account.

Future researches should take into account emotional marketing in designing marketing research. Furthermore, cross-national segmentation can be performed. In addition to selfreported consumption, data from retailers should be collected as well. Finally, organic food consumption might be considered not only in general and from frequency of consumption aspect, but also in the context of specific organic food categories and amounts of money spent for their buying.

\section{References}

Anderson, J.C. and Gerbing, D.W., 1982. Some Methods for Respecifying Measurement Models to Obtain Unidimensional Construct Measurement. Journal of Marketing Research, 19 (4), pp. 453-460.

Bahrami, H. and Evans, S., 2005. Super-Flexibility for Knowledge Enterprises: A Toolkit for Dynamic Adaption. s.l: Springer.

Bredahl, L. and Grunert, K.G., 1997. Food-related lifestyle trends in Germany 1993-1996. MAPP Working Paper 50, The Aarhus School of Business, Aarhus.

Briner, R., 2018. Bioeconomy Concepts. In: I Lewandowski ed., 2018. Bioeconomy: Shaping the Transition to a Sustainable, Biobased Economy. Hohenheim: Springer, pp. 17-38.

Brunsø, K., Fjord, T.A. and Grunert, K.G., 2002. Consumers' food choice and quality perception. MAPP Working Paper 77, The Aarhus School of Business, Aarhus.

Brunsø, K., Grunert, K.G. and Bredahl, L., 1996. An analysis of national and crossnational consumer segments using the food-related lifestyle instrument in Denmark, France, Germany and Great Britain. MAPP Working Paper 35, The Aarhus School of Business.

Bruwer, J., Li, E. and Reid, M., 2002. Segmentation of the Australian wine market using a wine-related lifestyle approach. Journal of Wine Research, 13 (3), pp. 217-242.

Cader, Y., 2007. Knowledge Management and Knowledge-based Marketing. Journal of Business Chemistry, 4 (2), pp. 46-58.

Chamber of Commerce and Industry of Serbia, 2015. Organic Production in Serbia. [pdf] Chamber of Commerce and Industry of Serbia. Available at: <http://www.pks.rs/ SADRZAJ/Files/OPC\%20Brosura\%20ENG.pdf> [Accessed 15 February 2018].

Churchill, G.A.Jr., 1979. A Paradigm for Developing Better Measures of Marketing Constructs. Journal of Marketing Research, 16(1), pp. 64-73

Clever Consult BVB, 2010. The Knowledge Based Bio-Economy (KBBE) in Europe: Achievements and Challenges. s.l: Clever Consult BVB.

D'Alisa, G., Demaria, F. and Kallis. G., 2014. Degrowth: A Vocabulary for a New Era. s.1: Routledge.

Danes, J.E. and Mann, O.K., 1984. Unidimensional Measurement and Structural Equation Models with Latent Variables. Journal of Business Research, 12(3), pp- 337-351. 
Davenport, T.H. and Prusak, L., 1998. Working Knowledge, How Organizations Manage What They Know. Boston: Harvard Business School Press.

Dayan, R., Heisig, P. and Matos, F., 2017. Knowledge management as a factor for the formulation and implementation of organization strategy. Journal of Knowledge Management, 21(2), pp. 308-329

Djokic, N. and Milicevic, N., 2016. Organic Consumer Profile and Obstacles for Increasing Consumption of Organic Food in Serbia. The Annals of the Faculty of Economics in Subotica, 53, pp. 65-77.

Đokić, I., Đokić, N., Pavlović, N., Kovač, P. and Žnideršić, R., 2014. Promotion of organic food in Serbia: implications from organic food consumers' profile research. Economics of Agriculture, 61(4), pp. 837-849.

Eisend, M., 2015. Have We Progressed Marketing Knowledge? A Meta-Meta-Analysis of Effect Sizes in Marketing Research. Journal of Marketing, 79, pp. 23-40.

European Commission, 2011. Bio-based economy in Europe: state of play and future potential-Part 2. Luxembourg: Publications Office of the European Union.

Fang, C.-H. and Lee, H.-J., 2009. Food-related lifestyle segments in Taiwan: Application of the food-related lifestyle instrument. American Journal of Applied Sciences, 6(12), pp. 2036-2042.

Grubor, A. and Djokic, N., 2016. Organic food consumer profile in the Republic of Serbia. British Food Journal, 118(1), pp. 164-182.

Grubor, A., Djokic, N., Djokic, I. and Kovac-Znidersic, R., 2015. Application of Health and Taste Attitude Scales in Serbia. British Food Journal, 117(2), pp. 840-860.

Grunert, K.G., Bruns $\emptyset$, K. and Bisp, S., 1993. Food-related life style: Development of a cross-culturally valid instrument for market surveillance. MAPP Working Paper 12, The Aarhus School of Business, Aarhus.

Hill, D., 2003. Rational mind, emotions connect for decisions. Marketing News, 37(19), p. 37.

Hill, D., 2007. Face Value. Marketing Research: A Magazine of Management \& Applications, 19(3), pp. 8-14.

Hill, D., 2008. Emotionomics: Leveraging Emotions for Business Success. s.l: Kogan Page.

Hill, D., 2017. Emotions Matter: How Facial Coding Can Better Connect You to Your Clients. Journal of Financial Planning, 30(6), pp. 24-26.

Hughes, T., Tapp, A. and Hughes, R., 2008. Achieving effective academic/practitioner knowledge exchange in marketing. Journal of Marketing Management, 24(1-2), pp. 221-240.

Hughner, R.S., McDonagh, P., Prothero, A., Shultz, C.J. and Stanton, J., 2007. Who are organic food consumers? A compilation and review of why people purchase organic food. Journal of Consumer Behavior, 6(2-3), pp. 94-110.

Inkinen, H., 2016. Review of empirical research on knowledge management practices and firm performance. Journal of Knowledge Management, 20(2), pp. 230-257

Kalentic, M., Stefanovic, E., Simic, I. and Maerz, U., 2014. Organic agriculture in Serbia At a Glance 2014. Belgrade: National Association „Serbia Organica“. 
Kesić, T. and Piri-Rajh, S., 2003. Market segmentation on the basis of food-related lifestyles of Croatian families. British Food Journal, 105(3), pp. 162-174.

Kim, S. and Lee, H., 2010. Factors affecting employee knowledge acquisition and application capabilities. Asia-Pacific Journal of Business Administration, 2(2), pp. 133-152

Lewandowski, I. ed., 2018. Bioeconomy: Shaping the Transition to a Sustainable, Biobased Economy. Hohenheim: Springer.

Magids, S., Zorfas, A. and Leemon, D., 2015. The New Science of Customer Emotions. Harvard Business Review, 93(11), pp. 68-77.

März, U., Stolz, T., Kalentić, M. and Stefanović, E., 2012. Organic agriculture in Serbia 2012 - At a Glance. Belgrade: National Association "Serbia Organica".

Maslac, T., 2009. Organic Agriculture in Serbia. Belgrade: USDA Foreign Agricultural Service.

McCormick, K. and Kautto, N., 2013. The Bioeconomy in Europe: An Overview. Sustainability, 5, pp. 2589-2608.

Newell, S., Robertson, M., Scarbrough, H. and Swan, J., 2002. Managing Knowledge Work and Innovation. s.l: Palgrave Macmillan.

Nonaka, I. and Takeuchi, H., 1995. The Knowledge-Creating Company. New York: Oxford University Press.

Nie, C. and Zepeda, L., 2011. Lifestyle segmentation of US food shoppers to examine organic and local food consumption. Appetite, 57, 28-37.

O'Sullivan, C., Scholderer, J. and Cowan, C., 2005. Measurement equivalence of the food related lifestyle instrument (FRL) in Ireland and Great Britain. Food Quality and Preference, 16(1), pp. 1-12.

Reid, M., Li, E., Bruwer, J. and Grunert, K.G., 2001. Food-related lifestyles in a crosscultural context: Comparing Australia with Singapore, Britain, France and Denmark. Journal of Food Products Marketing, 7(4), pp. 57-75.

Renko, N., Butigan, R., Renko, S., Vuletic, A., Barjolle, D., Zaouche-Laniau, M., Schaer, B., Berner, N., Eynaudi, D., Markovic, D., Tomic, L., Kendrovski, V., Bajic, B., Scepanovic, S., Stojanovic, Z., Stoikovic, D., Gligoric, M., Popovic, S., Klopcic, M. and Pohar, J., 2011. Market data, market trends and consumer behaviour report for organic products in the WBC. [online] Available at: <http://www.focus-balkans.org/ res/files/upload/file/DL7\%202_Market\%20data\%20market\%20trends\%20and\%20consu mer\%20behaviour\%20report\%20for\%20organic\%20products\%20in\%20the $\% 20 \mathrm{WBC}$ fi nal.pdf> [Accessed 20 February 2018].

Roth, M.S., Jayachandran, S., Dakhli, M. and Colton, D.A., 2009. Subsidiary Use of Foreign Marketing Knowledge. Journal of International Marketing, 17(1), pp. 1-29.

Rossiter, J.R., 2001. What is marketing knowledge? Stage I: forms of marketing knowledge. Marketing theory, 1(1), pp. 9-26.

Rossiter, J.R., 2002. The five forms of transmissible, usable marketing knowledge. Marketing theory, 2(4), pp. 369-380.

Ryan, I., Cowan, C., McCarthy, M. and O’Sullivan, C., 2004. Segmenting Irish food consumers using the food-related lifestyle instrument. Journal of International Food \& Agribusiness Marketing, 16(1), pp. 89-114. 
Rytel, T., 2010. Emotional marketing concept: the new marketing shift in the postmodern era. Business: Theory and Practice, 11(1), pp. 30-38.

Scholderer, J., Bruns $\varnothing$, K., Bredahl, L. and Grunert, K.G., 2004. Cross-cultural validity of the food-related lifestyles instrument (FRL) within Western Europe. Appetite, 42(2), pp. 197-211.

Steenkamp, J.E.M. and van Trijp, H.C.M., 1991. The Use of LISREL in Validating Marketing Constructs. International Journal of Research in Marketing, 8(4), pp. 283-99.

Simic, I., 2017. Organic Agriculture in Serbia At a Glance 2017. Belgrade: National Association Serbia Organica.

Sudarević, T., Salai, S. and Pupovac, Lj., 2011. Marketing aspekti ponude organskih poljoprivrednih proizvoda u Srbiji i okruženju. Anali Ekonomskog fakulteta u Subotici, 47(26), pp. 33-48.

Snyman, R. and Kruger, C.J., 2004. The interdependency between strategic management and strategic knowledge management. Journal of Knowledge Management, 8(1) pp. 5-19.

Szakály, Z., Szente, V., Kövér, G., Polereczki, Z. and Szigeti, O., 2012. The influence of lifestyle on health behavior and preference for functional foods. Appetite, 58(1), pp. 406-13.

Wedel, M. and Kamakura, W.A., 2002. Introduction to the Special Issue on Market Segmentation. International Journal of Research in Marketing, 19(3), pp. 181-183.

Wierenga, B., 2002. On academic marketing knowledge and marketing knowledge that marketing managers use for decision-making. Marketing theory, 2(4), pp. 355-362. 